\title{
Prismets profil gjennom 50 år (1950-2000)
}

\author{
Av Sverre Dag Mogstad
}

Tidsskriftet Prismet er 70 år $i$ 2020. Det har skjedd store forandringer fra forste årgang $i$ 1950 til dagens utgaver. Fra begynnelsen ønsket tidsskriftet å vore et kristent verdiforankret og ideologisk tidskrift. Artikkelen analyserer om forståelsen av pedagogikk og den kristne forankringen har endret seg gjennom de forste femti årene (1950-2000). Grunnleggerne av tidsskriftet fant den ideologiske forankringen $i$ det de kalte en "helhetspedagogikk» eller «integralpedagogikk» og i en luthersk kristendomsforståelse. Analysene viser at redaksjonene stort sett har beholdt denne forståelsen selv om det ideologikritiske har blitt dempet betraktelig og forståelsen av pedagogikk har blitt mer utydelig.

Nøkkelord: religionspedagogikk, helhetspedagogikk, kristen pedagogikk, pedagogisk historie, Prismet

Av Sverre Dag Mogstad (f. 1948), professor em. i religionspedagogikk ved MF vitenskapelig høyskole. Adr: Gydas vei 4, postboks 5144 Majorstuen, 0302 Oslo. E-post: sverre.d.mogstad@mf.no

\section{INNLEDNING}

Tidsskriftet Prismet feirer i år 70-årsjubileum. Det er derfor god grunn til å se tilbake på tidsskriftets 70 år. Alle tidsskrift forandrer seg over en så lang periode. Det har også Prismet gjort. Det har skjedd store forandringer fra første årgang i 1950 med ti hefter i året med vekt på en kristen pedagogikk for kirke, skole og samfunn, trykt på tykt papir og produsert av Arne Gimnes Forlag A/S til tidsskriftet i 2020 med 4 hefter i året, utgitt digitalt (Open Access) og godkjent som vitenskapelig publiseringskanal på nivå 1 med vekt på artikler i skjæringspunktet mellom pedagogikk, religion og teologi. I dag presenterer tidsskriftet seg som «et ledende nordisk fagtidsskrift innen religionspedagogikk, og målgruppen for tidsskriftet er alle som arbeider innen de religionspedagogiske praksisfeltene, samt forskere og studenter.» (iko.no/prismet - 11.2.2020)

Det er interessant å se nærmere på hvordan et kristent verdiforankret og ideologisk tidsskrift forandrer seg. En slik analyse kan og bør gjøres ut fra ulike perspektiv og metoder. I denne artikkelen skal jeg bare trekke frem ett perspektiv og spørre: Hvordan ser de grunnleggende ideologiske forandringene ut gjennom 50 år? Jeg har valgt to tema som kan vise slike forandringer. For det første gjelder det hvilken pedagogikk en legger til grunn. Med dette tema vil en kunne analysere tidskriftets ideologiske profil i forhold til samtidens allmennpedagogiske debatt.

Prismet - IKO-Forlaget 2020

Tilgjengelig på https://journals.uio.no/index.php/prismet. Publisert under CC BY-NC 4.o. Fagfellevurdert 
Den første etterkrigstiden og spesielt 1950-årene var preget av en omfattende pedagogisk nytenkning og debatt i Norge. Striden sto på mange måter mellom på den ene siden en positivistisk og psykologisk forankret tenkning, og en mer åndsvitenskapelig dannelsestradisjon på den andre siden. Det andre temaet er hvordan en forstår den kristne forankringen av pedagogikken. Det åpner for å kunne se hvordan tidsskriftet plasserer seg i forhold til ulike teologiske retninger og til indrekirkelige debatter. Selv om perspektivet for analysen er smalt, vil svarene på disse to spørsmålene kunne vise den ideologiske forankringen.

Denne analysen av tidsskriftets utvikling kunne med fordel også blitt satt inn i en større kulturell og politisk kontekst. Tidsskriftet har på mange måter stått i en kulturkritisk sammenheng hvor kulturelle og politiske stridsspørsmål har avløst hverandre. Slik sett har lederartiklene ofte vært skrevet innenfor rammen av en mer omfattende kulturkamp (Mogstad 1989).

Det er ikke gjort mange slike analyser av tidsskriftets utvikling. Men en undersøkelse bør nevnes. Steinar Moe skrev i 2000 en artikkel om hvordan en fra redaktørhold forholdt seg til innføringen av det nye KRL-faget i grunnskolen. (Moe 2000.) Han viser at tidsskriftet gjennomgår en forandring fra å tolke det nye faget $\mathrm{i}$ lys av det gamle kristendomsfaget til å si at faget ikke skal være opplæring til en bestemt tro og at myndighetene nå knytter begreper som nøytralitet og objektivitet til faget. Moes undersøkelse er interessant fordi den viser redaksjonens raske tilpassing til en ny pedagogisk og politisk virkelighet.

Jeg har valgt å legge stor vekt på den første lederen 1950 og se om den ideologien som presenteres der, opprettholdes og eventuelt vitaliseres gjennom 50 år. I den første lederen introduseres begge temaene jeg har valgt som analytisk tilnærming: «helhetspedagogikk» og «kristen pedagogikk». Det har vært en utfordring å velge hvilke lederartikler en i tillegg skulle velge å analysere. I hovedsak har jeg valgt ledere i forbindelse med redaktør- og redaksjonsskifter. Korte ledere kan ikke gi fyldige svar. Jeg har derfor valgt å supplere analysene med å trekke inn noen få utvalgte artikler som på en mer grundig måte gir substans til disse temaene. Selv om utvalget er smalt, vil likevel et slikt utvalg og en slik analyse kunne kaste et visst lys over tidsskriftets første 50 år.

En metodisk utfordring har vært at jeg selv var medredaktør i perioden 1985-2000. Hva dette har ført til av manglende perspektiver og kritisk holdning, er ikke godt å si. Men det har helt sikkert ført til skjeve vinklinger og viktige utelatelser. Å analysere tekst i spenningen mellom nærhet og distanse har vært utfordrende, men samtidig hatt både positive og negative sider.

\section{HISTORISK BAKGRUNN}

Opprettelsen av Prismet står i en større sammenheng. Allerede i 1909 var Norges kristelige lærerforbund etablert. Forbundet ga ut Kristelig pedagogisk Tidsskrift som 
siktet seg inn mot lærerne i folkeskolen. Som mange andre tidsskrifter og blader ble også dette stanset under krigen. Men i 1946 kom det ut i ny drakt under navnet Kristen Skole. Med tilleggstittelen «Før: Kristelig pedagogisktidsskrift» ønsket utgiverne med Bjarne Hareide i spissen å opprettholde kontinuiteten med Kristelig pedagogisk Tidsskrift. Men redaksjonen ønsket nå et tidsskrift som omfattet alle skoleslagene, ikke bare folkeskolen. Selv om interesse og fagnivå var forskjellig for de ulike skoleslagene, mente de at i det grunnleggende hadde en de samme midlene og målene. Ikke minst gjaldt dette den kristne pedagogikken. (Kristen Skole 1/1946, s.3.) Nå skulle en samle alle de kristne kreftene under ett tak. Redaktørstaben ble utvidet til 4, en fra hvert av skoleslagene: folkeskolen, ungdomsskolen, gymnaset og lærerskolen. Allerede i lederen i det første nummeret kommer det klart frem hva de overordnede målene med tidsskriftet var.

Og når no Fellesprogrammet krev karakterdanning, kan det etter norsk skulelov ikkje bli tale om anna enn ei kristeleg-moralsk karakterbygging. Her er det legitime program for norsk skule. Vi må berre ta konsekvensen av dette heilt ut. Det er det kristne livssynet og den kristne ånd som skal prege skulen vår. Det må berre gjennomforast på ein positiv og byggande måte. Skal dette bli røyndom, må det skapast ein sterk kristen pedagogikk. Det er ei forsomd oppgåve i dag. (Kristen Skole 1/1946, s.4.)

Her kommer det tydelig fram hvordan kristen og moralsk karakterdanning og kristen helhetspedagogikk blir hjørnesteinene i etterkrigstidens kristne skoletenkning i Norge. Dette gjenspeiler seg også i valget av redaktører: (Bjarne Hareide (ansvarlig), Anker Holmin, Erling Melberg og Trygve Stabrun). I tillegg presenterte det første nummeret en oversikt over 34 sentrale norske personer innenfor skole og kirke som var tilknyttet tidsskriftet som medarbeidere. I hefte nummer to samme år er listen utvidet med fire nye norske personer og med ni nordiske. Det ble med andre ord etablert et bredt nordisk, faglig og kirkelig nettverk rundt tidsskriftet.

Utgiverne ønsket å starte et fagtidsskrift og ikke et propagandablad. Tankene som skulle presenteres i tidsskriftet, skulle være underbygd faglig og vitenskapelig. Hovedparolen var å samle og aktivere de kristne pedagogiske kreftene ved å samle nye krefter fra hele landet og ved å informere om nyere pedagogisk tenkning $\mathrm{i}$ utlandet. Artiklene i det første nummeret avspeiler målsettingen. Håkon Wergeland skriver for eksempel i tidsskriftets første artikkel om «Personlegdanning». (Kristen Skole 1/1946, s.1ff) Han kritiserer pedagogene for å ha dyrket bare visse sider ved personlighetslivet. I stedet etterlyser Wergeland en personlighetsdanning som tar vare på helheten i personlivet i samsvar med det kristne livssynet.

\section{Den første utgaven av PRISMET (1950)}

Det første nummeret av Prismet kom ut i 1950 med undertittelen «Tidsskrift for skole og hjem». Utgiver var Institutt for Kristen Oppseding (IKO) som var en videre- 


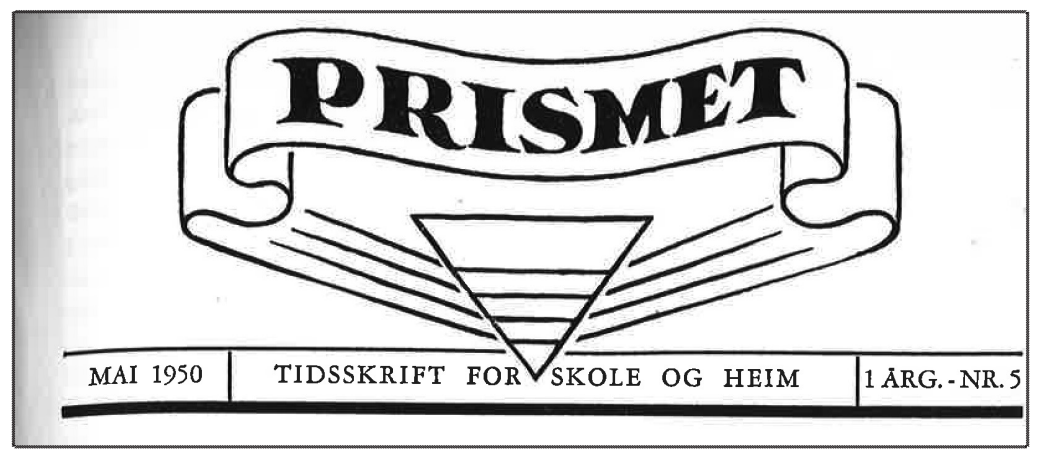

føring av Kristelig Pedagogisk Kontor som var etablert i 1945, men som skiftet navn til Institutt for Kristen Oppseding 1948. Redaktør var Bjarne Hareide, mens Åge Holter og Trygve Stabrun var redaksjonssekretærer. Hareide var redaktør til og med 1969, men i de siste årene fungerte redaksjonssekretær Aasmund Dale i praksis som redaktør.

Prismet var et av flere tiltak som Hareide og kretsen omkring han iverksatte etter krigen med sikte på å gjenreise et kristent og pedagogisk arbeid for kirke, skole og hjem. Særlig sentralt sto arbeidet med å styrke kristendomsfaget i skolen. I den første lederen presenterer Hareide tidsskriftets program: «En helhetspedagogikk som omfatter både det menneskelige samfunnet og Guds rike.» (Prismet 1/1950, s.5) Han skrev at pedagogikken i dag var preget av de mange pedagogiske sekterismer, og skolens svøpe var fagtrengsel, pensumtvang, kunnskapsjag og karakterbegjær. Den barnesentrerte pedagogikken blir egosentrisk og selvopptatt. Selv om den nye sosialpedagogikken skulle korrigere den egoistiske isolasjonen som individualismen førte mennesket til, overser den at mennesket er noe mer enn samfunnsborgere. Sammenfattende skriver han:

Med all vår pedagogiske og psykologiske aktivitet og alle våre retninger, foler det moderne menneske seg like rådvill og hjelpeløs $i$ den vanskeligste av alle oppgaver som er lagt på skapningen, oppdragelsen av den oppvoksende slekt. (Prismet 1/1950, s.5)

Med navnevalget Prismet ville tidsskriftet være det midlet som skulle fange opp og bryte alle strålene fra nyere pedagogikk. Det skulle presentere noe mer enn en «immanens-pedagogikk». Alternativet var en kristen helhetspedagogikk.

Mennesket trenger en saklig pedagogikk, og da ikke bare den sak som heter det sosiale, det moralske, det åndelige eller et annet livsfelt, men vi må vinne fram til helheten. Vi må komme bort fra de mange pedagogiske sekterismer og skape en integralpedagogikk.

Derfor tør vi også bruke det krevende ord: en kristen pedagogikk. (Prismet 1/1950, s.5)

Men dette betød ikke for Hareide en begrensing av oppgavene til bare å gjelde kristendomskunnskap og religionspedagogikk. Ut fra luthersk teologi understrekte 
han at en også hadde fătt en borgerlig oppgave som hørte til skaperordningene og Guds lov. Og den krevde normer. Og det er med dette utgangspunktet han skriver at «vår helhetspedagogikk vil omfatte både det menneskelige samfunn og Guds rike». Tidsskriftet skulle altså ikke begrense seg til å føre en indrekirkelig samtale. Tvert om var hele det pedagogiske feltet og hele den allmennpedagogiske debatt samtalepartnere. Tidsskriftet skulle være en kritisk stemme inn i samtiden forankret $i$ en kristendomsoppfatning som forstod barn og unge både som kristne og samfunnsborgere. Dette dobbelte perspektivet ble viktig for å kunne bli hørt både i kirke og samfunn.

Med denne lederen knytter Hareide Prismet til ideene og målsetningene i det tidligere tidsskriftet Kristen Skole. Men nå blir kristen pedagogikk og helhetspedagogikk satt inn i en større pedagogisk sammenheng. Allerede i det første heftet ser en hvordan målsetningene i lederen blir konkretisert. Artiklene blir plassert under faste tema som går igjen i alle heftene. Under Aktuell metodikk skriver Trygve Stabrun om hvordan en skal lære elevene rasjonell lekselesing. Under Ideer og brytninger skriver Åge Holter om pedagogikk på skilleveier. Her analyserer og sammenlikner han den franske filosofen Jacques Maritains ny-thomistiske pedagogikk og Johannes Sandvens nye bok om pedagogiske idebrytninger i USA (Dewey og pragmatismen, den ny-aristoteliske tradisjonalismen og essensialismen). Holters konklusjon står som et godt eksempel på tidsskriftets profil:

Men mennesket er på en og samme tid individ og person, og til det svarer to forskjellige poler for min moralske og indre utvikling: jeg kan utvikle meg i retning av personlighet, dvs. en uavhengighet og en selvbeherskelse som svarer til mitt åndsprinsipp, eller jeg kan utvikle meg i retning av individualitet, dvs. en overgivelse til de tendenser som er $i$ meg ved arv og materie. Pedagogikken bor her besinne seg på at disse to delene ikke faller fra hverandre. En integral oppseding har det hele mennesket i sikte: den individuelle person. Tidens pedagogiske hovedsynd er at man sikter på det individuelle istedenfor det personlige og dermed reduserer menneskets oppseding og utvikling til en simpel frigjoring av det materielle jeg. Derfor er det man sammenblander barnets frihet med dyrets spontanitet, derfor avsettes loveren som barnets moralske leder og autoritet og blir til en foyelig og overfledig assistent, derfor kan man også tale om bankerot for oppsedingen og for de voksnes ansvar overfor ungdommen. (Prismet 1/1950, s.11)

Det tredje temaet har overskriften Ecclesia. Her tar Olav Nome opp spørsmålet om katekismen. Med denne artikkelen går han inn i en aktuell debatt om katekismens framtid i skole og i kirke. Konteksten for artikkelen er fjerningen av katekismen fra skolen i Sverige, Berggravs bok fra 1936: Fornyelse av katekismen samt Harald Aspås bok: Luthers katekisme som lærebok $i$ dag fra 1948. Spørsmålet som sto i sentrum var om katekismen først og fremst var en pedagogisk lærebok eller et bekjennel- 
sesskrift. Utfordringen var om det ville være mulig med en forsiktig revisjon av teksten som kunne forene de to standpunktene? (Prismet 1/1950, s.16ff)

Den fjerde temaet har Heim og folk som overskrift. Forfatteren og læreren Magnhild Haalke skriver om oppfostring til fred. Hun hevder at arbeidet for fred starter med barna i hjemmene. Derfor er foreldregjerningen så viktig. Og familiene trenger en lettere økonomisk situasjon, bedre boliger og lettere arbeid. Løsningen finner Haalke ikke overraskende innenfor individualetikk og tradisjonell kjønnsideologi:

Her må kvinnene velge: Familien eller yrkeslivet. Et menneske har begrenset kraft og evner. Morsarbeidet, oppdragergjerningen er et spesialarbeide, det kan ikke klare seg med en som springer ut om morgenen og kommer heim, sliten og trott etter mange timers yrke - for å vore mor! Storparten av oppdragergjerningen faller jo på henne, for det faren alltid må ut på fortjeneste til underhold, ofte langt fra heimen. (Prismet $1 / 1950$, s.29)

I tillegg til de faste temaartiklene hadde man allerede fra første hefte også en rekke faste spalter som viser tidsskriftets pedagogiske bredde og målsetning. I spalten Pedaglobus presenteres og analyseres aktuell pedagogisk debatt fra mange land: Frankrike (den franske barnerepublikken Moulin-Vieux), Sverige (intelligensmåling), Danmark (lærerideal), Tyskland (kristendomsundervisning eller religionsundervisning), Ungarn (plutokratisk-kapitalistisk pedagogikk), USA (akademisk frihet og kommunistfrykt) og Østerrike (obligatorisk kristendomsundervisning). Presentasjonene og analysene er til dels fyldige og skarpe, og viser at tidsskriftet ønsker å være en stemme i den større pedagogiske debatten i Norge.

I den faste spalten kalt Presserevy kommenteres skoledebatt fra aviser rundt om i landet. I dette første heftet er det innslag fra flere aviser om spørsmålet om lekser: Tiden (Arendal), Stavangeren, Stavanger Aftenblad, Arbeiderbladet, Samhold (Gjøvik), Hedmarkens Amttidende (Kongsvinger) og Verdens Gang. Både tema og argumentasjon er gjenkjennbar fra vår egen tid.

To mindre spalter kalles Har de lest? og Vi har lest. I den første spalten presenteres med noen få ord i hovedsak utenlandsk (fransk, engelsk og tysk) faglitteratur, mens den andre spalten inneholder korte bokanmeldelser.

Samlet sett presenterer Prismet seg med en klar målsetning, og det er imponerende hvor vidt redaksjonen satser. For å forstå denne omfattende satsingen av ressurser på et kristent pedagogisk tidsskrift, må en ha klart for seg endringen i kultursituasjonen i den første perioden etter krigen. Under krigen hadde en greid å etablere en bred politisk og ideologisk enighet mellom foreldre, kirke og skole på foreldrerettens og kirkens grunn. (Harbo 1989; Mogstad 1989) Denne alliansen søkte flere å videreføre etter krigen. Men den ble motarbeidet både fra et kulturradikalt miljø i Arbeiderpartiet og fra «dissenterhold». 
Flere av redaksjonens medlemmer kjente også godt til finsk, luthersk teologi og den religionspedagogiske utvikling i Tyskland etter krigen. I Tyskland fikk den såkalte «Evangelische Unterweisung» en enerådende stilling. Frykten for en ny ideologisering av skolen og samfunnet førte til en åpen og positiv holdning til kirkens selvråderett for å unngå ny statlig overstyring. Den nye teologien ble forstått som bekjennelsesteologi og betraktet som et effektivt våpen mot eventuelle ideologiske utfordringer fra statens side. Og den evangeliske undervisningen ble sett på som en konsekvent gjennomføring av den nye teologien (Kittel 1947). Kittel mente at denne undervisningens ideologiske funksjon og dens muligheter til å formidle skapertro, var det beste middelet til å frigjøre elevene fra alle ideologiske virkelighetsoppfatninger og til å sette dem fri til å møte virkeligheten. I Norge ble denne ideologikritikken brukt mot «angrepene» på kristen innflytelse innenfor kultur og politikk.

Gradvis vokser det derfor fram en kulturkamp om skolen. Og striden kom i særlig grad til å stå om kristendomsfagets plass og innhold. Men som den første lederartikkelen presiserer, ble ikke tidsskriftets oppgave begrenset til det spesielt kristne. Tanken om en helhetspedagogikk og allmenn fostring ble forankret i en luthersk teologi hvor både Gud og verden hørte kristentroen til. (Dale1978)

Allerede i 1950 ble spørsmålet om hva som menes med en «kristen pedagogikk» behandlet på lederplass. Her argumenteres det mot å forstå denne som en ideologisk retning som skulle presse det kristne livssynet inn i alle fag og inn i all livsstil på linje med totalitære livssyn som ønsker makt over skolen og oppdragelsen.

Kristen pedagogikk vil alltid kjempe for kristendomsfaget sin rett og plass i skule og samfunn - både frå eit kristent synspunkt og eit sosiologisk, men han kan aldri tvinge ein viss ideologi inn i dei andre fagene - av den enkle grunn at kristendom ikkje er ideologi. Difor er all einsretting eit framandelement i evangelisk pedagogikk. (Prismet 6/1950, s.173)

I lederen brukes Luthers toregimentslære til å gi allmennfagene faglig frihet slik at mennesket blir satt i stand til å leve et «nestekjærleiksliv» i verden og i Guds skaperordninger. Toregimentslæren ga allmennfagene frihet til å utvikle sine egne faglige synspunkter basert på fagenes vitenskapelighet slik at en unngikk «kristen» overprøving og sensur. Med denne teologiske forankring av skolefagene argumenterte en for at kristendomsfaget skulle presentere kristen tro med et innenfraperspektiv samtidig som allmennfagene skulle beholde sine egne faglige strukturer upåvirket av enhver kristen sensur. Denne balansegangen ga faglig frihet for alle skolefagene, men var ikke alltid like lett å praktisere. 


\section{«TIÅRSJUBILEUM» (1960)}

I lederen i hefte $1 / 1960$ vises det tilbake til den første lederartikkelen i 1950. I hovedsak gjentas de samme målsetningene som den gang. Den barnesentrerte skole vil lett føre til dominerende egosentrisistet, og sosialpedagogikken omdanner lett mennesket til statsdirigerte borgere. Som alternativ til disse pedagogiske retningene settes på ny «en integralpedagogikk som orienterte seg ut fra det kulturgrunnlag og det livssyn som er konstituerende for den vesterlandske kulturkrets, det kristelig-humanistiske».

Det er en optimistisk lederartikkel som står på trykk nå ved inngangen til et nytt tiår. På tross av harde debatter om kristendomsfaget, en skolepolitikk hvor «sentrale kristelige åndsverdier» har stått på spill og hvor det gamle samarbeidsforholdet mellom kirke og skole var på vei til å brytes opp, ser en klare lyspunkter.

Klarere enn for har det demret dette siste desennium at kanskje det kristne grunnsyn kan gi sammenheng og mening. Skolen så vel som pedagogikken har voert i ferd med å atomiseres. Helheten blir borte i tusen detaljer, i fagtrengsel og emnekonkurranse. Den sprenges ikke bare av mangeartet stoffmengde, men enda mer av motstridende momenter innen samme pensum. Spenningsmomentene blir så store at de splitter barnesinnet.

Her stär kristendomskunnskapen som det sentrale fag, - ikke bare som et fag ved siden av de andre og et viktig sådan, men det som samler trådene i sentrum og et skolens åndelige grunnlag. Det gir nemlig ikke bare sammenheng mellom fagene, men det som viktigere er, sammenheng mellom undervisning og oppseding.

Integrasjon i egentlig mening oppnår en bare ved et bestemt menneskebilde og et helhetssyn, og det finner vi i vår folkelige kulturtradisjon bare på kristendommens mark. (Prismet 1/1960, s.5f)

Denne lederen uttrykket kanskje mer ubeskyttet enn tidligere hvordan kristendomsfaget bør være skolens sentrum, og hvordan en kristent forankret integral pedagogikk kan forene skolens fag i en dannelsestradisjon. Hvis man ikke leser dette i lys av en luthersk toregimentslære, står en i fare for å gjøre kristentroen til en ensrettende ideologi. Det er derfor ikke overraskende at det i samme hefte publiseres en artikkel av Reidar Myhre med tittelen: "Helhetspedagogikk». (Prismet 1/1960, s.11ff)

Myhre viser hvordan den nye positivistiske pedagogikken blir forankret i sosiologi og biologisk basert psykologi slik at «områder og fenomener som gir det menneskelige sjeleliv dets egenart som for eksempel vilje, samvittighet, frihet og ansvar overhodet ikke berøres». (Prismet 1/1960, s.12)

Helhetspedagogikken har til felles med den positivistiske pedagogikken at den starter i empirien. Men i motsetning til denne, starter helhetspedagogikken i en fenomenologisk og ikke positivistisk empiriforståelse. Dermed stenger den 
ikke ute en rekke fenomener som ikke er tilgjengelig i en naturvitenskapelig tenkning. Myhre fremholder i tråd med denne tenkningen at livet er mer enn materie, og at det fremtrer gjennom kvaliteter og strukturer som krever sin egen erkjennelsesform. (ibid s.13) Gjennom en fenomenologisk analyse går en direkte til saken slik den ytrer seg i sin naturlige sammenheng. Dette medfører at den vitenskapelige pedagogikks gjenstand verken er barnet eller oppdrageren, men relasjonen mellom disse - i spenningen mellom et jeg og et $d u$. Motsetningen til denne analytiske tilnærmingen er å forstå relasjonen som et forhold mellom et jeg og et det. Men siden den pedagogiske situasjonen alltid er innvevd i kulturmønstre, og disse kan være mange og ulike, vil den pedagogiske analyse alltid måtte avdekke disse kulturmønstrene. Myhre viser her et klart avhengighetsforhold til den jødiske filosofen Martin Buber.

Ut fra denne analyse får man grunnlag for å forstå hvordan de helhetsoppfatninger, systemer, livsanskuelser som fins i kulturen, gjor seg gjeldende i pedagogikken, hvordan pedagogikken ifolge sitt vesen uløselig er knyttet til alle kulturens og livets områder, at grunnsynet i eksistensanalysen klinger igjen $i$ alle avgjorende faser $i$ den pedagogiske prosess. Ut fra en slik tolkning av pedagogikken lar det seg gjore å tale om en helhetspedagogikk. (Prismet 1/1960, s.12)

Myhre fremhever også at denne pedagogiske analysen, som i utgangspunktet er deskriptiv og ikke preskriptiv, ikke sier hvilken helhetsoppfatning eller syntese en bør velge. Dermed kan pedagogikken aldri være allmenngyldig eller et lukket kausalsystem. Den belyser bare valgmulighetene. Valget må pedagogen selv ta under et eksistensielt ansvar. Helhetspedagogikk er med andre ord ikke enhetspedagogikk. Det er derfor Prismet fra første hefte presiserer at det står for en kristen helhetspedagogikk, og at den omfatter både det menneskelige samfunnet og Guds rike. En avviser med andre ord samtidens deskriptive og kvantitative forankrete pedagogikk hvor en søker å avlede normer av «sin mer eller mindre eksakte vitenskap» (Prismet 1/1960, s.30).

Hefte nummer én i 1960 inneholder en fyldig indeks for tidsskriftets ti første år. Denne vitner om at målsetningen fra 1950 er ivaretatt. Her er både «verden og Guds rike» i skole, kirke og hjem rikelig analysert. Men sett i ettertid er ikke alle analysene like holdbare. Et eksempel på dette er debatten om «rytmiske aktiviteter» i forbindelse med Læreplan for forsøk med 9-årig skole. Forslaget utløste en omfattende pressedebatt. Motstanden mot å føre dans inn i skolen var omfattende. Da Prismet behandlet spørsmålet på lederplass (Prismet 7/1960, s.197), sies det at det neppe er noe spørsmål ved siden av kristendomsfagets svake plassering i planen, som har skapt større debatt enn innføring av selskapsdans i gymnastikktimene. Motstanden sammenfattes i to punkter. Innføring av selskapsdans vil skape samvittighetsnød hos mange foreldre, og det vil skape strid i skolen 
som ender i tillitskrise mellom skole og hjem. En avviser at denne argumentasjonen er kulturfiendtlig. Den er tvert om kulturkritisk, hevdes det. Argumentasjonen er basert på erfaringer fra foreninger og ungdomslag som har sluppet dansen inn i sitt program. For her sitter man igjen med bitre erfaringer fordi dansen har fortrengt de ideelle interessene, og danselokalet har skapt et kaldt og hardt miljø. Men det viktigste argumentet som anføres er at dans i skolen vil føre til en håpløs uro og strid. Et emne som fører til så diametralt motsatte meninger, hører ikke hjemme i skolen. For skolen skal representere gjennomsnittet av hjemmene.

Tidsskriftet har i den første tiårsperioden en rekke artikler og kommentarer om kristendomsfagets plass i skolen. Den underliggende tankegangen er at faget skal være kirkens dåpsundervisning. Derfor er det viktig at evangeliet skal få lyde i klasserommet. En advarer mot at fagets innhold blir historisert eller moralisert. Tilgivelsen og nåden må nå den enkelte elev. Forståelsen av kristendomsfaget minner på mange måter om den tyske «Kirke i Skole»-tenkningen. Dermed er det lett å forstå hvorfor en fra kirkelig hold oppfattet skoledebatten som en kulturkamp. Selv om en i Prismet understreket at kristentroen ikke var en ideologi, men tvert om representerte det nødvendige hinderet for at skolen ikke skulle ideologiseres, ser en nok i ettertid at tidsskriftets første periode også var preget av en ideologiserende bruk av kristentroen.

\section{REDAKTØRSKIFTET I 1970}

Med hefte 1/1970 ble det gjennomført er redaktørskifte i tidsskriftet. Bjarne Hareide blir skiftet ut med Aasmund Dale. I en artikkel i hefte 8/1970 kalt «Strømlinjer gjennom 25 år» foretar Hareide en oppsummering av IKOs og Prismets virksomhet siden starten. Her peker han på 25 års to store utfordringer: kristendomsfagets plass og innhold i skolen (Hareide 1956) og dåpsopplæringens plass i kirken (UPRO). Målsetningen var en fornyelse av kristendomsfaget og Guds ord inn i hjemmene. I denne sammenhengen så han nødvendigheten av å hjelpe skolefolk og andre pedagoger med stipendier til kvalifiseringsutdannelse og forskning. Med dette grepet skaffet han seg en stadig voksende gruppe medarbeidere med høy faglig kompetanse.

Med Dale fikk tidsskriftet en redaktør som videreførte Hareides målsetninger, men samtidig en som var mildere i formen. Det redaksjonelle arbeidet med tidsskriftet videreføres først med de samme spaltene og med det samme brede faglige «hjelpeapparatet». Men etter hvert endrer tidsskriftet oppbygning. De mange faste spaltene blir færre, og de som tidvis beholdes, blir ikke så omfattende.

I sin første lederartikkel skriver Dale om enhetsskolens plass i et stadig økende pluralistisk samfunn. I denne sammenheng blir «70-årenes store folkepedagogiske oppgave å lære mennesket å spørre etter de egentlige verdier i livet, og gi rom for utfoldelse av alle sider ved et sant menneskelig liv». (Prismet 1/1970, s.5) 
Konkluderende skriver han:

En liten leder i Prismet kan slett ikke gi svaret. Men, som Prismet har gjort $i$ de foregående to tiår, vil vårt tidsskrift vise hva som horer det sanne menneskeliv til, hvilke pedagogiske folger dette har, og hvilke organisatoriske tiltak som må til for at forholdene kan legges til rette for søken etter verdier og for livsutfoldelse, både $i$ den store folkelige enhet og i de ulike livssynsgrupper. (Prismet 1/1970, s.5)

Dales ledere er preget av de samme utfordringene som tidligere, men han er forsiktigere enn Hareide med å polarisere motsetninger. I det samme heftet som Hareide skrev skarpt om strømlinjene gjennom IKOs 25 første år, spør Dale i lederen om IKOs arbeid mer har vært kritikk av lavere timetall og av-konfesjonalisering enn et arbeid for kristen oppseding og undervisning. Dette «mot»-arbeidet mener han er et resultat av at protester og offensiver er blitt tvunget inn på IKO som viktige oppgaver fordi viktige verdier har stått på spill. Men samtidig skriver han at den som kjenner IKO, vet at det er andre ting som har preget hverdagen: hjelp til lærere, planarbeid, kurs og foredrag, foreldremøter osv. Det er tydelig at Dale innser at tidsskriftets kulturkamp har fått slagside. En har fătt for stor oppmerksomhet mot hva som er galt fremfor å presentere de gode alternativene. Dermed ligger det nært å kritisere tidsskriftet for å ha gjort kristentroen til en ideologi.

Lederen i hefte 9/1970 er et godt eksempel på i hvilken form Dale velger å behandle stridsspørsmål. Her skriver han om Normalplanutvalgets innstilling om kristendomsfaget i grunnskolen. I stedet for en fortsatt kamp om timetallet, skulle han ønske at en nå kunne samle seg om innholdet i faget og om arbeidsformene. Han advarer mot å skyve problemet med det lave timetallet over på kommunene; og til motspørsmålet: Hvilke fag skal avgi timer til kristendomsfaget; eller til at de andre fagene må ha så og så stort timetall; eller til at mange lærere synes det er nok timer til faget. I stedet for å ta utgangspunkt i slike spørsmål, leverer han en positiv begrunnelse for økt timetall:

Ta heller hensyn til det faktum at hva kristendomsfaget skal arbeide med, er viktigere enn noen sinne. Snakk heller om at faget må ha godt med tid når så viktige emner skal fa en anstendig behandling. Gi heller dette faget en slik tidsramme at de arbeidsformer det krever, kan bli tatt i bruk. Og argumenteres det med at faget ikke oppleves aktuelt for eleven, så gå til sakens kjerne: Lag en ny plan, en plan som fra år til år gir plass for det aktuelle. Ikke for å finne på noe nytt, men fordi intet fag er mer aktuelt, og intet fag har eleven mer krav på å oppleve aktuelt enn kristendomsfaget. Det gjelder jo livet! (Prismet 9/1970, s.261)

Med Dale som redaktør beholder Prismet sin målsetning og strategi. Men det skjer en gradvis endring som både skyldes redaktørenes ulike personlighet og at den skolepolitiske og kulturelle konteksten er annerledes på 1970-tallet enn 
hva den var på 1950-tallet. En kan også merke at satsingen på en vitalisering av dåpsopplæringen både i kirken og $\mathrm{i}$ hjemmene, og på reformarbeidet med konfirmasjonsundervisningen, fører til en forsiktigere språkbruk om kirke i skolen og om kristendomsfagets sentrale funksjon i synet på skolens enhet. Det er flere årsaker til dette, ikke minst grunnskoleloven fra 1969 som gjorde kristendomsfaget til et ordinært skolefag begrunnet pedagogisk og kulturelt i foreldreretten og ikke lenger i kirkens dåpsopplæring.

En leder fra hefte 7/1976 illustrerer kirkens nye dilemma med hensyn til forholdet mellom kirke og skole. Det vises til spenningen mellom på den ene siden de formelle bestemmelsene som fortsatt består om det kristne innslaget $\mathrm{i}$ grunnskolen, og realitetene blant foreldre og lærere på den andre siden. Men selv om kirken har overtatt ansvaret for dåpsopplæringen, argumenterer lederen for at kirken ikke kan forlate skolen. Og hovedbegrunnelsen er at det er kirkens barn som går i skolen, og dette ansvaret kan ikke kirken løpe fra. (Prismet 7/1976, s.276) Det mest interessante i denne lederen er den nye begrunnelsen for kirkens plass i skolen. Nå er begrunnelsen knyttet til at elevene er kirkens barn (de døpte), og det gir kirken rett og plikt til å ta ansvar for barna også i deres skoletid. Borte er nå den første etterkrigstidens tanke om at kristendomsfaget er den nødvendige overbygningen som sikrer skolen og skolefagenes frihet fra ideologisering.
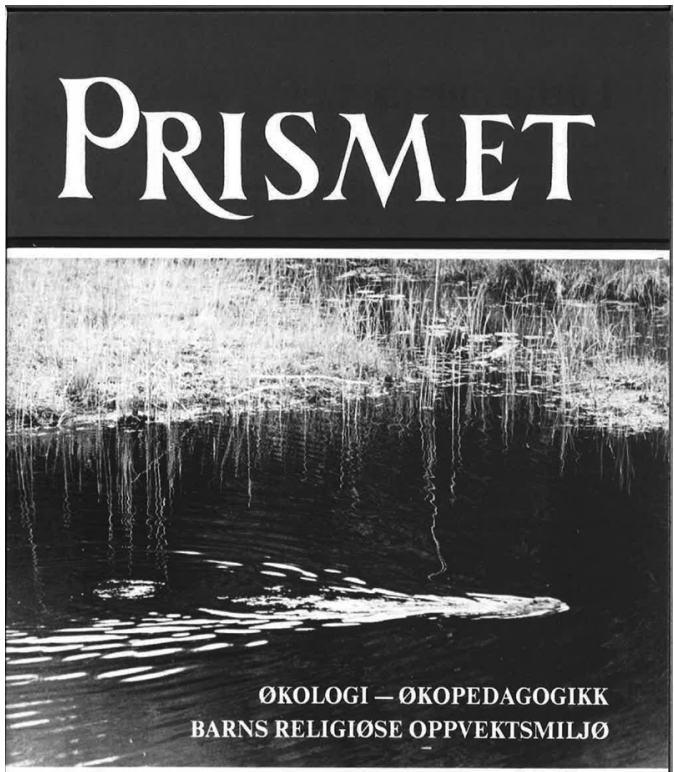

PEDAGOGISK TIDSSKRIFT 1-1980
I 1980 ba Dale om avløsning som redaktør. Løsningen ble at instituttlektor Birger Henrik Fossum ble ny redaktør samtidig som Dale fortsatte som redaktør, men nå som faglig rådgiver $\mathrm{i}$ redaksjonen. Fossum fungerte som medredaktør til og med hefte nummer 2/1983. I denne perioden varierer det hvem som skriver lederen. Det kan enten være en av redaktørene eller en annen fra redaksjonsstaben. Av mer prinsipielle spørsmål som behandles er debatten om privatskolenes plass og rettigheter. I hefte 4/5 i 1980 skriver Dale at ut fra elementære demokratiske rettigheter og menneskerettighetene, er det viktig at eiere av private livssynsskoler sikres 
retten til å ansette lærere som deler skolens livssyn. I ettertid ser vi at striden om slike ansettelser bare er i startgropen på begynnelsen av 1980-tallet, men Prismet har tatt et klart standpunkt i saken. I hefte 9/10 samme år behandler lederen en annen utfordring for de kristne privatskolene. Nå gjelder det styringsretten, og her tar også tidsskriftet et klart standpunkt.

Det står kamp om privatskolen. Denne gangen gjelder det styringsretten. Styresammensetningen for de private skolene må vare slik at eieren er sikret et flertall i styret.

Private kristne skoler er opprettet $i$ en bestemt hensikt, og det fremmer ikke demokratiet a komme med inngrep som kan bringe disse institusjonenes egenart i fare. (Prismet 9/10 1980, s.267)

Friskoleloven er forankret i foreldrenes rett til å bestemme over sine barns undervisning og oppdragelse. I Danmark hvor det er større utbredelse av friskoler, er det derfor foreldregrupper som står som eiere, mens det i Norge i hovedsak er organisasjoner. Det lederen ikke tar stilling til, er spørsmålet om på hvilken måte organisasjonenes ideologiske forankring korresponderer med foreldrenes syn på styring av skolene.

\section{Et viktig MELlomspill 1983-1985}

Aasmund Dale fortsatte som medredaktør ut året 1983. Fra hefte 3/1983 tiltrådte Trond Eilif Hauge som redaktør. Med Hauge som redaktør fikk Prismet en velkvalifisert pedagog i ledelsen. Han hadde disputert på en avhandling om åpen-skole-bevegelsen. Allerede i sin første leder understreker han nødvendigheten av at skolen fokuserer på det hele mennesket, og hvordan skolen blir et sted å lære om hva det vil si å leve med hverandre. I samme hefte skriver han en viktig artikkel om kristen oppdragelse som utfordring i 80-årene. Denne oppdragelsen forankrer han i en allmenn pedagogikk preget av trygghet, omsorg, meningsfullhet, ansvar og selvtillit. Det spesifikt kristne ved oppdragelsen er dens forankring $\mathrm{i}$ et kristent menneskesyn. Det innebærer en realistisk virkelighetsorientering hvor både oppdrager og barn er underordnet de samme autoritative grenser for sine handlinger.

Jeg oppfatter dette som en helt spesiell spydspiss inn i oppdragelsens virkelighet. For grensene for handling knyttes til Gud selv og ikke til oppdrageren og ham alene, eller fellesskapet alene. (Prismet 3/1983, s.84)

Med Hauge som redaktør har tidsskriftet på en ny måte etablert en ny faglig bro mellom pedagogikken og kristentroen. I flere ledere og artikler anvender Hauge denne fagforståelsen i sine kritiske analyser av blant annet ny stortingsmelding og ny mønsterplan for grunnskolen. Tidsskriftets profil er blitt å tale elevenes sak i skolens hverdag. Og det innebærer som det uttrykkes i flere ledere i Hauges 
periode, at en ikke må stoppe ved prinsippspørsmålene, men at en må gå aktivt inn for å bidra til nødvendige fagfornyelser.

I forlengelsen av denne utfordringen skriver han en leder kalt: «Noen religionspedagogiske utfordringer». (Prismet 1/1985, s.3) Han hevder at religionspedagogikken må styrkes for å kunne greie å gjennomføre en nødvendig nytenkning og omstilling for å møte nye utfordringer i barns og unges oppvekstsituasjon. For å gjennomføre dette må religionspedagogikken gå inn i en konstruktiv samtale med pedagogikken. Implisitt i hans utfordring ligger en kritikk mot en rådende teologisk bestemmelse av religionspedagogikken.

Religionspedagogikken blir fattig om oppdragelsesprisippene ene og alene skal preves mot teologiske prinsipper. Det samme skjer når pedagogikken forlanger forkjorsrett og framstår som den eneste leverandor av oppdragelsesverdiene. (Prismet 1/1985, s.3)

Med denne lederen åpner han for den kommende debatten om religionspedagogikkens forankring. Men kort tid etter blir Hauge bedt om å gå av som redaktør av IKOs instituttstyrer. Avgangen blir begrunnet med at han ikke lenger har så nær tilknytning til institusjonen. Hauge har nå blitt spurt om han kunne fungere som sekretær for arbeidet med Mønsterplan 87. I det første heftet etter avgangen er det instituttstyrer Finn Wagle som skriver en programmatisk leder. Han advarer mot at kirken bare blir opptatt av seg selv, at den tenker altfor smått om sin egen rolle som kulturbærer og dermed står i fare for å glemme å være kirke i verden og for verden.

I dette perspektiv står Prismet overfor en rekke spennende utfordringer. I alle år har det vart liten tvil om Prismets religionspedagogiske utgangspunkt og kirkelige forankring. (Prismet 5/1985, s.127)

I ettertid ligger det nært å spørre om redaktørskiftet i 1985 skal forstås som et uttrykk for en korrigering av den profilen Hauge hadde signalisert i sin redaktørperiode.

\section{REDAKTØRGRUPPER FRA 1985}

Etter Hauges avgang som redaktør etablerte instituttstyrer Finn Wagle en redaktørgruppe med tre medlemmer. Gruppen ble satt sammen med sikte på å dekke ulike sider ved tidsskriftets brede temafelt. Gruppen besto av sokneprest Per Karstensen, forskningsstipendiat Sverre Dag Mogstad og høyskolelektor Ragnhild Veiteberg. Skolekonsulent Erling Birkedal ved IKO ble ny redaksjonssekretær. De nye redaktørene satset på å videreføre tidsskriftets profil med en blanding av pedagogiske temanummer rettet mot kirke og skole, og analytiske artikler om skolepolitiske spørsmål. Den ideologiske forankringen ble skjerpet allerede i den første lederen, som har overskriften En kristen pedagogikk. Etter å ha sitert Hareides første leder fra hefte 1/1950 med tilslutning, fortsetter lederen: 
Prismet må fortsatt virke for en kristen pedagogikk. En pedagogikk som setter barnet i sentrum og lar barnet få lov til å være barn. Men dette oppnår vi ikke før barnet settes $i$ rett forhold til Gud og verden. Det er derfor mitt håp og ønske at den pedagogiske debatt og informasjon i Prismet skal hjelpe skole, kirke og hjem, teoretisk og praktisk, med å innholdsbestemme kristen oppdragelse og kristen undervisning. Med det mener vi ikke en oppdragelse og undervisning bare for kristne mennesker, men en som gjelder alle og hele mennesket, fordi Gud har skapt oss alle til å tjene ham $i$ kirke og samfunn. (Prismet 6/1985, s 159)

Lederartikkelen viser en tilslutning til den ene siden av Hauges målsetning, nemlig fokus på barnet og eleven. Samtidig signaliserer den en korrigering av den ideologiske forankringen. Mens Hauge åpnet for en sterkere pedagogisk forankring av religionspedagogikken, er tidsskriftet med denne lederen tilbake til en teologisk forankring. Et eksempel på dette er en artikkel i nr. 8/86 om hva kristen oppdragelse er. Her bestemmes oppdragelsen i lys av den lutherske toregimentslæren som både all god oppdragelse som korresponderer med Guds gode skapervilje, og som all virksomhet som legger til rette for at barnet kan nås med evangeliet. Den samme tilnærmingen ser en i en leder hvor temaet er kristendom og kultur.

Selv om en i luthersk teologi kan plassere kulturen som en funksjon av Guds fortsatte skapergjerning, vil enhver samtid måtte trekke opp grenser mellom kristendom og kultur. Ikke all kultur er kristen kultur. Derfor vil kristentroen alltid måtte ha en kulturkritisk funksjon. En slik oppgave vil både innebore å avdekke kulturens ideologiske funksjon i samfunnet, men også dens mulighet til å formidle kristen tro og tradisjon. (Prismet 4/1987, s.99)

Et annet eksempel på den teologiske tilnærmingen til pedagogikken ser en i en leder med overskriften Kristen realisme.

En kristen realisme innebarer både en realistisk virkelighetsoppfatning og muligheten til å forandre verden. I skolen vil både kristendomsfaget og de andre fagene ha som oppgave å framstille verden og mennesket på en sann måte. En kristelig sensurert presentasjon er ikke bare usann, den er også pedagogisk uforsvarlig. Men skolen må også gi rom for kristentroens framtidshåp. (Prismet 5/1987, s.135)

Ut over på 80- og 90-tallet ble det foretatt ulike endringer i redaktørgruppen. I 1990 hadde dosent Sigmund Harbo avløst Per Karstensen og høyskolelektor Kjellfrid Mæland avløst Ragnhild Veiteberg. Og i 1995 var Erling Birkedal blitt ansvarlig redaktør med Harbo, Mogstad og Mæland som medredaktører. Dette var en ordning for å sikre større nærhet mellom instituttet og tidsskriftet. I denne perioden fikk heftene en sterkere karakter av å være temahefter som for eksempel: Eventyr, Musikk, En kirke for alle, Aids, Familiepedagogikk, Midtøsten, Satanisme, 
Selvmord. Med disse heftene ønsket en å gi pedagoger i kirke og skole faglig og pedagogisk støttelitteratur. Også tidsskriftets lederartikler fikk med dette en mer tematisk karakter knyttet til temaheftenes profil.

\section{0-tallet: Nye UtFordRinger}

En rekke lederartikler på 90-tallet tar opp spørsmål knyttet til den nye debatten om religionsundervisningen i skolen. Prismet ga full støtte til utviklingen av det nye KRL-faget med NOU-instillingen Identitet og dialog som grunnlag. Dette var ingen overraskelse fordi innstillingens leder Erling Pettersen var nå blitt instituttstyrer ved IKO. (For en mer inngående gjennomgang av tidsskriftets holdning til utviklingen av KRL-faget, kan en se Steinar Moes artikkel: «Fram mot KRL synspunkter i Prismet» (Prismet 5/2000, s.199ff).) På lederplass sies det:

Faget skal både hete og i realiteten vare et kristendomsfag, med kristen tro og tradisjon som hovedinnhold og hovedperspektiv, ikke et nøytralt orienteringsfag av filosofisk eller religionsvitenskapelig art. Det foreslås dessuten at faget fortsatt skal vore konfesjonelt forankret. (...) Sist, men ikke minst, er denne modellens levedyktighet avhengig av at en $i$ horingsfasen fär en konstruktiv debatt - ikke minst fra kirke og organisasjonshold - der en i noen grad er villig til a dimensjonere scerinteresser i forhold til den historiske sjanse vi nå har til å sikre en framtid for kristendomsfaget i norsk grunnskole.

(Prismet 4/1995, s. 143)

I samme årgang skrives det på lederplass:

En felles skole for alle elever med et felles kristendomsfag for alle vil nettopp kunne bli det sted hvor vår felles kultur- og livssynsarv formidles til nye generasjoner. Derfor må spørsmålene omkring livssynsminoritetene og kulturminoritetenes rettigheter underordnes de overordnede formålene. Det betyr ikke at minoritetene skal overkjores, men det betyr at minoritetsspersmålet ikke må få lov til å utvanne kristendomsfagets og skolens innhold. (Prismet 5/1995, s. 189)

Begge disse lederne er eksempler på hvordan redaksjonen stilte seg bak det nye faget som Identitet og dialog målbar, samtidig som en trakk forståelsen av faget i retning av et fornyet kristendomsfag. Men allerede i 1998, ett år etter at det nye KRL-faget var innført, ser en at redaksjonen korrigerer sin forståelse og prøver å tilpasse seg den nye målsettingen for faget.

En folge av den nye fagforståelsen er at nå skal de samme pedagogiske prinsippene legges til grunn for arbeidet med kristendommen og andre religioner og livssyn. Det betyr at alle religionene og livssynene skal presenteres ut fra deres egne saklige og faglige strukturer. Den nye fagforståelsen og den likestilte didaktikken bor nå utfordre kirken til å gjennomtenke sitt forhold til skolen på nytt. .... Foretok vi et tilsvarende arbeid $i$ Norge, ville vi også kunne fä lagt grunnlaget for kirkens ansvar for sin egen kateketiske undervisning. (Prismet 1/1998, s. 1) 
I en senere lederartikkel i samme årgang følges dette opp idet en viser til at faget ifølge 1969-loven ikke lenger er kirkens dåpsundervisning.

Tross den økende fare for sekularisering som oppstår når dåpsundervisningen «vandrer ut» fra den offentlige grunnskolen, kan en slik situasjon også framtvinge en "hjemreise» med ny ansvarsmobilisering og nye vekstvilkår for kirkelig undervisning. Dåpsopploeringens plass er jo forst og fremst $i$ menighet og familie.

Både kirken og skolen framtrer nå $i$ storre grad enn for som to selvstendige og myndige institusjoner med ansvar for hver sin karakteristiske formidlingsoppgave. Kirken skal forkynne og gi trosopplaring, skolen skal undervise. Til dette formål har en ulike profesjoner. Kirken har prester og kateketer, skolen har loerere. Men kristendommen $i$ de to institusjonene er den samme. (Prismet 6/1998, s.241)

Selv om en holder fast på at fagets innhold er det samme som tidligere, ser en nå mot slutten av tusenåret at Prismet toner ned den ideologiske forståelsen av faget som en hadde femti år tidligere. Da ble faget forstått som skolens sentrum og som vern mot fremmed ideologisering av skolen. Nå oppfordres kirken til å akseptere at skolen er blitt myndig. Samtidig utfordres kirken til å videreføre arven med å formidle evangeliet til barn og unge. Det kommer klart fram i en leder i 1999 hvor det heter: «Dåpsundervisningens utvandring fra skolen er altså noe langt mer enn et nederlag for kristentroens framtid i Norge. Det er snarere en historisk utfordring vi ikke kan la ligge.» (Prismet 5/1999, s. 197)

Men på et annet punkt videreføres og fornyes arven fra den første redaksjonen. Det gjelder tanken om en helhetspedagogikk.

En kristen helhetspedagogikk kan ikke ta utgangspunkt i en idealistisk forståelse av virkeligheten, men $i$ den faktiske virkelighet, slik den foreligger på godt og ondt. Så langt vi kan se, gir det nye KRL-faget oss denne muligheten. Faget åpner for at den enkelte elev kan få styrket sin egen identitet, samtidig som elevene blir satt $i$ stand til å forstå og fungere $i$ et sammensatt religiøst og kulturelt samfunn. Men samtidig har Kirken fätt nye utfordringer. En ny kirkelig pedagogikk må utvikles, hvor utgangspunktet må vare et kristent kunnskapsbegrep med kirken og menigheten som kontekst. Her gjenstår det et omfattende arbeid. (Prismet 4/1999, s.141)

I 2000 kunne tidsskriftet feire 50 år. Det ble markert med et eget jubileumsnummer. (Prismet 5/2000) På lederplass viser en til at tidsskriftet i 1976 ukommentert endret undertittelen fra «Tidsskrift for skole og heim» til «Pedagogisk tidsskrift». Redaktøren spør om dette bare var en verbal forandring eller et signal om kursendring. Ved tusenårsskiftet kan en se at et nytt syn på religionsundervisningens begrunnelse, pedagogikk og innhold forenes med den tidligere tanken om en helhetspedagogikk. Dermed oppstår det både brudd og kontinuitet med den opprinnelige visjonen for tidsskriftet. Profilen har ikke lenger en så sterk uttalt 
ideologisk forankring som 1950-tallets kulturkamp krevde. Den har nå fått en ny kontekst som krever endringer. Kanskje er redaktørens påstand i jubileumsheftet «litt» sann:

Prismets profil ligger imidlertid fast. Det ønsker å vere et åpent forum der ulike bidrag til undervisning og oppdragelse i hjem, skole kan presenteres og brytes. Men nettopp åpenheten og dialogen krever et sentralperspektiv om ikke helheten skal forsvinne. Prismets ståsted er den kristne tros- og virkelighetsoppfatning. (Prismet 5/2000, s. 197)

På ett punkt skiller Prismet seg fra mange andre tidsskrifter. Gjennom de første femti årene trer ikke tidsskriftets ideologiske forankring frem bare gjennom lederartikler. Tvert om ser en at alle artiklene og alle spaltene formidler den overordnede forankring og målsetting. Det innebærer at redaksjonen har hatt en «streng» og bevisst hånd når forfattere har blitt spurt om å skrive artikler. På denne måten har heftene og årgangene fått en klar profil og stått i tjeneste for en overordnet målsetning.

\section{ETterord}

I 2005 gjennomgikk tidsskriftet en nødvendig radikal omlegging. Redaktører ble Roger Jensen (studierektor IKO) og Erling Birkedal (direktør IKO) som sammen skulle ivareta den teologiske og pedagogiske kompetansen. Målsetningen med omleggingen var å skape en klarere profil og tydeligere bevissthet om målgruppe for tidsskriftet samtidig som en skulle ivareta Prismets tidligere målsetninger i forhold til hjem, skole og kirke.

Prismet har gjennom sin 50-årige historie hatt som målsetning å veere oppdatert og vere et sentralt samtalested i forhold til de utfordringer som «hjem, kirke og skole» står overfor $i$ spørsmål om pedagogikk og innhold i religionsfaget, og om religiøs identitet.

De er store, utfordringene som $i$ årene fremover vil sette dagsorden innenfor disse feltene. (Prismet 1/2005, s. 2)

Tidsskriftets omlegging i 2005 viderefører først og fremst 50-tallets ønske om at Prismet ikke skulle være et propagandablad, men et vitenskapelig forankret tidsskrift. Om omleggingen har videreført målsetningen om en kristen pedagogikk for kirke, skole og samfunn, er et åpent spørsmål.

\section{LITTERATUR}

Aspås, Harald 1948: Luthers katekisme som lærebok i dag. Ei pedagogisk vurdering med eit framlegg til skuletekst på grunnlag av vedkjenning og altarbok Oslo: Fabritius Berggrav, Eivind 1936: Fornyelse av katekismen. Motivert forslag til norsk tekst for Luthers katekismus utarbeidet efter opdrag av Kirkedepartementet. Oslo; Gyldendal 
Dale, Aasmund 1978: «Bjarne Hareide. Noen streker til et bilde» i Ivar Asheim (red.): Vekst og kunnskap i kirke og folk. Festskrift til Bjarne Hareide. Oslo; Luther Harbo, Torstein 1989: «Kirken, foreldrene og skolen i møte med staten» i Brynjar Haraldsø (red.): Kirke - skole - stat. 1739-1989. Oslo: IKO-Forlaget, s.105ff.

Hareide, Bjarne 1956: Skal kristendommen ut av skolen? Oslo; Lutherstiftelsen

Kittel, Helmuth 1957: Vom Religionsunterricht zur Evangelischen Unterweisung. Berlin; Schroedel.

Kristen skole. Før: Kristelig pedagogisk tidsskrift. Oslo. 1946-1949.

Moe, Steinar 2000: «Fram mot KRL. Synspunkter i Prismet» i Prismet 5/2000, s.199ff.

Mogstad, Sverre Dag 1989: «Kirken i kulturkampen om skolen» i Brynjar Haraldsø (red.): Kirke - skole - stat. 1739-1989. Oslo: IKO-Forlaget, s.132ff.

Prismet. Pedagogisk tidsskrift. Utgitt av Institutt for Kristen Oppseding. Oslo 1950-2005

UPRO. Undervisningsprogram for hjem og kirke. Oslo: IKO-Forlaget 1978.

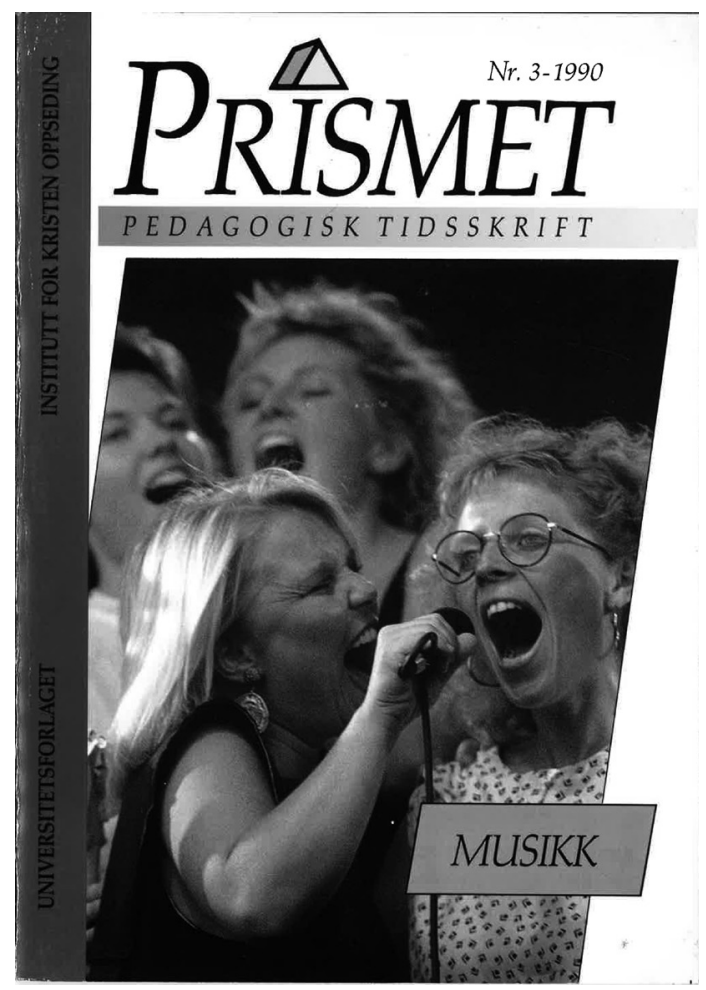

